\title{
The Study of Tourism
}

Foundations from Psychology

Philip L. Pearce Editor

Tourism

Social

Science

Series

Volume 15 


\title{
References
}

\author{
Albert, H.
}

1967 Marktsoziologie und Entscheidungslogik. Neuwied: Luchterhands.

Association of American Medical Colleges

1999 Assessment of Professionalism Project. < http://www.aamc.org/members/gea/

professionalism.pdf\#search $=\% 22$ definition $\% 20$ of $\% 20$ professionalism $\% 22>$

(Accessed October 8, 2006).

Baerenholdt, J., M. Haldrupi, J. Larsen, and J. Urry

2004 Performing Tourist Places. Aldershot: Ashgate.

Bagozzi, R.

1980 Causal Models in Marketing. New York, NY: Wiley.

Bagozzi, R., and P. Dabholkar

2000 Discursive Psychology: An Alternative Conceptual Foundation to Means-

End Chain Theory. Psychology \& Marketing 17:535-586.

Bagozzi, R., and U. Dholakia

1999 Goal Setting and Goal Striving in Consumer Behavior. Journal of Marketing

63(Special Issue):19-32.

Baloglu, S., and M. Uysal

1996 Market Segments of Push and Pull Motivations: A Canonical Correlation

Approach. International Journal of Contemporary Hospitality Management

$8(3): 32-38$.

Baumeister, R., and B. Bushman

2008 Social Psychology and Human Nature. Belmont, CA: Thomson Higher

Education.

Becher, $\mathrm{T}$.

1989 Academic Tribes and Territories: Intellectual Enquiry and the Culture of

Disciplines. Milton Keynes: Open University Press.

Bell, P., J. Fisher, and R. Loomis

1978 Environmental Psychology. Philadelphia. PA: W.B. Saunders.

Benckendorff, $P$.

2010 Exploring the Limits of Tourism Research Collaboration: A Social Network

Analysis of Co-Authorship Patterns in Australian and New Zealand Tourism

Research. In Proceedings of the 20th Annual CAUTHE Conference. Hobart,

Australia.

Biswas-Diener, $\mathbf{R}$.

2008 Material Wealth and Subjective Well-Being. In The Science of

Subjective Well-Being, M. Eid, and R.J. Larsen, eds. New York, NY: Guilford

Press. 
Bitgood, S.

2002 Environmental Psychology in Museums, Zoos, and Other Exhibition

Centers. In Handbook of Environmental Psychology, R.R. Bechtel, and

A. Churchman, eds., pp. 461-480. New York, NY: Wjley.

2006 An Analysis of Visitor Circulation: Movement Patterns and the General Value Principle. Curator 49:463-475.

2009 Museum Fatigue: A Critical Review. Visitor Studies 12(2):1-19.

Blaug, $M$.

1962 Economic Theory in Retrospect. Cambridge: Cambridge University Press.

Bochner, S. ed.

1982 Cultures in Contact. Oxford: Pergamon.

Booms, B., and M. Bitner

1981 Marketing Services by Managing the Environment. Cornell Hotel and

Restaurant Administration Quarterly 23(1):35-40.

Boring, E.

1950 A History of Experimental Psychology (2nd edition). New York, NY:

Appleton-Century-Crofts.

Bourdieu, P.

1986 The Forms of Capital. In Handbook of Theory and Research for the

Sociology of Education, J. Richardson, ed., pp. 241-258. New York, NY:

Greenwood Press.

Bowen, D., and J. Clarke

2009 Contemporary Tourist Behaviour. Wallingford: CABI.

Bramwell, B., and B. Lane

2005 From Niche to General Relevance? The Journal of Tourism Studies 16(2):52-62.

Braun, K., R. Ellis, and E. Loftus

2002 Make My Memory: How Advertising Can Change Our Memories of the

Past. Psychology and Marketing 19:1-23.

Brückner, $\mathrm{P}$.

1967 Die Informierende Funktion der Wirtschaftswerbung. Berlin: Duncker \&

Humblot.

Butler, R.

1980 The Concept of a Tourism Area Life Cycle of Evolution. Canadian

Geographer 24(1):5-12.

Campbell, C.

1987 The Romantic Ethic and the Spirit of Modern Consumerism. Basil: Blackwell.

Choi, S., X. Lehto, and J. O'Leary

2006 What Does the Consumer Want from a DMO Website? A Study of US and

Canadian Tourists' Perspectives. International Journal of Tourism Research 9:59-72.

Cialdini, $\mathrm{R}$.

2009 Persuasion: The Science and Practice. Needham, MA: Pearson Education. 
Cialdini, R., and N. Goldstein

2002 The Science and Practice of Persuasion. Cornell Hotel and Restaurant Administration Quarterly 43(2):40-51.

Cohen, E.

1972 Towards Sociology of International Tourism. Social Research 39: 164-182.

1979a A Phenomenology of Tourist Experiences. Sociology 13:179-201.

$1979 \mathrm{~b}$ Rethinking the Sociology of Tourism. Annals of Tourism Research 6:18-35.

1995 Contemporary Tourism - Trends and Challenges: Sustainable Authenticity

or Contrived Post-Modernity? In Change in Tourism: People, Places

Progresses, R. Butler, and D. Pearce, eds., pp. 12-29. London: Routledge.

Cohen, S., and L. Taylor

1976 Escape Attempts. The Theory and Practice of Resistance to Everyday Life.

London: Routledge.

Collett, $\mathrm{P}$.

2004 The Book of Tells. Australia: Doubleday.

Cooper, C.

2006 Knowledge Management and Tourism. Annals of Tourism Research $33: 45-58$.

Cosgrove, I., and R. Jackson

1972 The Geography of Recreation and Leisure. London: Hutchinson University

Library.

Crompton, $\mathbf{J}$.

1979 Motivations for Pleasure Vacation. Annals of Tourism Research 6:408-424.

1981 Dimensions of the Social Group Role in Pleasure Vacations. Annals of

Tourism Research 8:550-568.

2005 Issues Related to Sustaining a Long Term Research Interest in Tourism. The

Journal of Tourism Studies 16(2):34-43.

Crotts, J.

2004 The Affect of Cultural Distance on Overseas Travel Behavior. Journal of

Travel Research 42:186-190.

2008 Book Review: Why Choose This Book? How We Make Decision. Tourism

Analysis 13:345-346.

Crotts, J., A. Aziz, and A. Raschid

1998 Antecedents of Supplier's Commitment to Wholesale Buyers in the

International Travel Trade. Tourism Management 19:127-134.

Crotts, J., and A. Pizam

2003 The Effect of Natronal Culture on Consumers' Evaluation of Travel Services.

Journal of Tourism, Culture and Communications 4(1):17-28.

Crotts, J., and B. McKercher

2005 Visitor Adaptation to Cultural Distance on Visitor Satisfaction: The Case of

First Time Visitors to Hong Kong. Tourism Analysis 10:385-391. 
Crotts, J., and D. Wilson

1996 An Integrated Model of Buyer-Seller Relationships in the International

Travel Trade. Progress in Tourism and Hospitality Research 1(2):1-15.

Crotts, J., and G. Turner

1999 Determinants of Intra-Firm Trust in Buyer-Seller Relationships in the

International Travel Trade. International Journal of Contemporary Hospitality Management 11(2-3):116-123.

Crotts, J., and J. van Rekom

1998 Exploring and Enhancing the Psychological Value of a Fine Arts Museum.

Tourism Recreation Research Journal 23(1):31-38.

Crotts, J., and R. Erdmann

2000 Does National Culture Influence Consumers Evaluation of Travel Services?

A Test of Hofstede's Model of Cross Cultural Differences. Managing Service Quality 10:410-419.

Crotts, J., and S. Litvin

2003 Cross-Cultural Research: Are Researchers Better Served by Knowing

Respondents' Country of Birth, Residence, or Citizenship? Journal of Travel

Research 42:186-190.

Crotts, J., and W. van Raaij, eds.

1994 The Economic Psychology of Travel and Tourism. Binghamton, NY:

Haworth Press.

Crotts, J., C. Coppage, and A. Andibo

2001 Trust-Commitment Model of Buyer-Seller Relationships. Journal of

Hospitality and Tourism Research 25:195-208.

Csikszentmihalyi, $\mathrm{M}$.

1975 Beyond Boredom and Anxiety. San Francisco, CA: Jossey Bass.

1990 Flow: The Psychology of Optimal Experience. New York, NY: Harper

Perennial.

Dann, G.

2007 The Life and Times of a Wandering Tourism Researcher. In The Study of

Tourism Anthropological and Sociological Beginnings, D. Nash, ed., pp. 76-92.

Amsterdam: Elsevier.

Dann, G., D. Nash, and P. Pearce

1988 Methodology in Tourism Research. Annals of Tourism Research 15:1-28.

de Botton, A.

2004 Status Anxiety. London: Penguin.

Deci, E.

1975 Intrinsic Motivation. New York, NY: Plenum Press.

Diamond, J.

2005 Collapse: How Societies Choose to Fail of Survive. London: Penguin.

Diener, E., and R. Biswas-Diener

2008 Happiness: Unlocking the Mysteries of Psychological Wealth. Oxford: Blackwell. 
Dolnicar, S., and B. Grün

2007 How Constrained a Response: A Comparison of Binary, Ordinal and Metric

Answer Formats. Journal of Retailing and Consumer Services 14:108-122.

Dunn-Ross, E., and S. Iso-Ahola

1991 Sightseeing Tourists' Motivation and Satisfaction. Annals of Tourism

Research 18:226-237.

Eisenhardt, $\mathrm{K}$.

1989 Building Theories from Case Study Research. Academy of Management

Review 14:532-550.

Elrod, T., G. Russell, A. Shocker, R. Andrews, B. Bayus, J. Carroll, R. Johnson,

W. Kamakura, P. Lenk, J. Mazanec, V. Rao, and V. Shankar

2002 Inferring Market Structure from Customer Response to Competing and

Complementary Products. Marketing Letters 13:219-230.

Erez, M., and P. Early

1993 Culture, Self-Identity, and Work. New York, NY: Oxford University Press.

Evans, R.

1980 The Making of Social Psychology. New York, NY: Gardner Press.

Fesenmaier, D., C. Pena, and J. O'Leary

1992 Assessing the Information Needs of Indiana Convention and Visitor

Bureaus. Annals of Tourism Research 19:571-573.

Fesenmaier, D., H. Werthner, and K. Wöber, eds.

2006 Destination Recommendation Systems: Behavioral Foundations and

Applications. Wallingford: CABI.

Field, D., and J. O'Leary

1973 Social Groups as a Basis for Assessing Participation in Selected Water

Activities. Journal of Leisure Research 5(Spring):16-25.

Fischer, G.

1974 Einführung in die Theorie Psychologischer Tests. Bern: Huber.

Flyvbjerg, B.

2001 Making Social Science Matter. Cambridge: Cambridge University Press.

Fondness, D.

1994 Measuring Tourist Motivations. Annals of Tourism Research 21:555-581.

Franke, N., and J. Mazanec

2006 The Six Scientific Identities of Marketing: A Vector Quantization of

Research Approaches. European Journal of Marketing 40:634-661.

Fredrickson, B.

2001 The Role of Positive Emotions in Positive Psychology: The Broaden-and-

Build Theory of Positive Emotions. American Psychologist 56:218-226. Frey, A.

1961 Advertising (3rd edition). New York, NY: Ronald Press.

Frochet, I., and A. Morrison

2000 Benefit Segmentation: A Review of Its Applications to Travel and Tourism

Research. Journal of Travel and Tourism 9(4):21-45. 
Fuchs, S.

1992 The Professional Quest for Truth: A Social Theory of Science and

Knowledge. Albany, NY: State University of New York.

Furnham, A.

1984 Tourism and Culture Shock. Annals of Tourism Research ${ }^{\star} 11: 41-57$.

200850 Psychology Ideas You Really Need to Know. London: Quercus.

Gentry, J., S. Jun, and P. Tansuhaj

1995 Consumer Acculturation Processes and Cultural Conflict: How General-

izable Is a North American Model for Marketing Globally. Journal of Business

Research 32:129-139.

Gardner, H.

1995 Leading Minds and Anatomy of Leadership. New York, NY: Basic Books.

Getz, D., J. Carlsen, and A. Morrison

2004 The Family Business in Tourism and Hospitality. Wallingford: CABI.

Gladwell, $M$.

2008 Outliers: The Story of Success. New York, NY: Little, Brown and Company. Goeldner, C.

2005 Reflections of the Historical Role of Journals in Shaping Tourism

Knowledge. Journal of Tourism Studies 16(2):44-51.

Grabler, K., G. Maier, and J. Mazanec, eds.

1996 International City Tourism, Analysis and Strategy. London: Pinter.

Graburn, N.

1995 The Past in the Present in Japan: Nostalgia and Neo-traditionalism in

Contemporary Japanese Domestic Tourism. In Change in Tourism: People,

Places, Progresses, R. Butler, and D. Pearce, eds., pp. 47-70. London: Routledge.

Gunn, C.

2004 Prospects for Tourism Planning: Issues and Concerns. Journal of Tourism

Studies 15(1):3-7.

Hartvig-Larsen, H. ed.

1998 Cases in Marketing. London: Sage.

Hatzinger, R., and J. Mazanec

2007 Measuring the Part-Worth of the Mode of Transport in a Trip Package: An

Extended Bradley-Terry Model for Paired-Comparison Conjoint Data. Journal of Business Research 60(12):1290-1302.

Hawking, St.

1993 Black Holes and Baby Universes and Other Essays. London: Bantam.

1997 The Objections of an Unashamed Reductionist. In The Large, the Small

and the Human Mind, R. Penrose, ed., pp. 169-172. Cambridge: Cambridge

University Press.

Hofstede, G.

1980 Culture's Consequences: International Differences in Work-Related Values.

Beverly Hills, CA: Sage.

Hofstede, G., and J. Hofstede

2001 Culture's Consequences (2nd edition). Thousand Oaks, CA: Sage. 
Hofstede, G., and M. Bond

1988 The Confucius Connection: From Cultural Roots to Economic Growth.

Amsterdam: Elsevier.

Hofstede, J., A. Audenaert, J. Steenkamp, and M. Wedel

1998 An Investigation into the Association Pattern Technique as a Quantitative

Approach to Measuring Means-End Chains. International Journal of Research

in Marketing 15(February):37-50.

Howard, J.A., and J.N. Sheth

1969 The Theory of Buyer Behavior. New York, NY: Wiley.

Hruschka, H., and J.A. Mazanec

1990 Computer-Assisted Travel Counseling. Annals of Tourism Research 7(2): 208-227.

Hsieh, S., J.T. O'Leary, and A.M. Morrison

1992 Segmenting the International Travel Market Using Activities as a

Segmentation Base. Tourism Management 13(2):209-223.

Hsu, C.H.C., and S. Huang

2008 Travel Motivation: A Critical Review of the Concept's Development. In

Tourism Management Analysis, Behaviour and Strategy, A. Woodside, and

D. Martin, eds., pp. 14-27. Wallingford: CABI.

Hsu, C., and J. Crotts

2006 Segmenting Mainland Chinese Residents Based on Experience, Intention and

Desire to Visit Hong Kong. International Journal of Tourism Research 8:279-287. Hudson, S.

1999 Consumer Behaviour Related to Tourism. In Consumer Behaviour in

Travel and Tourism, A. Pizam, and Y. Mansfield, eds. New York, NY:

Haworth Press.

Hunt, J.D.

1968 Tourist Vacations - Planning and Patterns. Logan: Utah Agricultural

Experiment Station, Bulletin 474.

1975 Image as a Factor in Tourism Development. Journal of Travel Research 13(3): $1-7$.

1988 State Tourism Offices and Their Impact on Tourist Expenditures. Journal of

Travel Research 26(3):10-13.

Hunt, J.D., and D. Layne

1991 Evolution of Travel and Tourism Terminology and Definitions. Journal of

Travel Research 29(4):7-11.

Hwang, C.L., and K. Yoon

1981 Multiple Attribute Decision Making: Methods and Applications: A State-ofthe-Art Survey. Berlin: Springer.

Iso-Ahola, S.E.

1980 The Social Psychology of Leisure and Recreation. Dubuque, IA: W.C.

Brown Co. Publishers.

1982 Toward a Social Psychological Theory of Tourism Motivation: A Rejoinder. Annals of Tourism Research 9(2):256-262. 
1983 Toward a Social Psychology of Recreational Travel. Leisure Studies 2(1):4546.

1989 Motivational Foundations of Leisure. In Understanding Leisure and

Recreation: Mapping the Past, Charting the Future, E.L. Jackson, and T.L. Burton, eds., pp. 35-51. State College, PA: Venture Publishing.

Iso-Ahola, S.E., and J. Allen

1982 The Dynamics of Leisure Motivation: The Effects of Outcome on Leisure

Needs. Research Quarterly for Exercise \& Sport 53:141-149. Jafari, J.

2005 Bridging Out Nesting Afield Powering a New Platform. Journal of Tourism Studies 16(2):1-5.

2007 Entry into a New Field of Study: Leaving a Footprint. In The Study of

Tourism: Anthropological and Sociological Beginnings, D. Nash, ed., pp. 108-121.

Amsterdam: Elsevier.

Jang, S., B. Bai, G. Hong, and J.T. O'Leary

2004 Understanding Travel Expenditure Patterns: A Study of Japanese

Pleasure Travelers to the United States by Income Level. Tourism Management 25:331-341.

Jang, S., L.A. Cai, A.M. Morrison, and J.T. O'Leary

2005 The Effects of Travel Activities and Seasons on Expenditure. International

Journal of Tourism Research 7(6):335-346.

Jansen-Verbeke, M., and J. van Rekom

1996 Scanning Museum Visitors: Urban Tourism Marketing. Annals of Tourism

Research 23(2):364-375.

Jewell, B., and J. Crotts

2001 Adding Psychological Value to Heritage Tourism Experiences. Journal of

Travel and Tourism Marketing 11(4):13-28.

2009 Adding Psychological Value to Heritage Tourism Experiences Revisited.

Journal of Travel and Tourism Marketing 16(3):244-263.

Kahle, L.

1986 The Nine Nations of North America and the Values Basis for Geographic

Segmentation. Journal of Marketing 50(April):37-47.

Kelley, L., B. MacNab, and R. Worthley

2006 Crossvergence and Cultural Tendencies: A Longitudinal Test of the Hong

Kong, Taiwan and United States Banking Sectors. Journal of International

Management 12(1):67-84.

Kivela, J., and J. Crotts

2006 Tourism and Gastronomy: Gastronomy's Influence on How Tourists

Experience a Destination. Journal of Hospitality and Tourism Research 30(3):354-377.

Klenosky, D.B., C.E. Gengler, and M.S. Mulvey

1993 Understanding the Factors Influencing Ski Destination Choice: A Means-

End Analytic Approach. Journal of Leisure Research 25(4):362-379. 
Klenosky, D., E. Frauman, W. Norman, and C. Gengler 1998 Nature-Based Tourists Use of Interpretive Services: A Means-End Investigation. Journal of Tourism Studies 9(2):26-36.

Kluckhohn, C. 1954 Culture and Behavior. New York, NY: Free Press.

Kluckhohn, C., and H.A. Murray

1967 Personality in Nature, Society and Culture (2nd edition). New York, NY: Knopf.

Kotler, P., J. Bowen, and J. Makens

1998 Marketing for Hospitality and Tourism. Uppersaddle River, NJ: PrenticeHall.

Kozak, K., J. Crotts, and R. Law 2007 The Impact of the Perception of Risk on International Travelers.

International Journal of Tourism Research 9:233-242.

Kozak, M., and A. Decrop 2009 Handbook of Tourist Behaviour. New York, NY: Routledge.

Krippendorf, J. 1987 The Holiday Makers: Understanding the Impact of Leisure and Travel.

London: William Heinemann.

Kroeber-Riel, W. 1975 Konsumentenverhalten. Munich: Vahlen.

Krueger, R., and M. Casey 2000 Focus Groups--A Practical Guide for Applied Research (3rd edition). London: Sage.

Langer, E. 1989 Mindfulness. Reading, MA: Addison-Wesley.

Lashley, C.

2000 In Search of Hospitality: Towards a Theoretical Framework. International Journal of Hospitality Management 19(1):3-15.

Lashley, C., and A. Morrison, eds.

2000 In Search of Hospitality: Theoretical Perspectives and Debates. Oxford:

Butterworth Heinemann.

Lehto, X.Y., L. Cai, J. O'Leary, and T.C. Huan 2004 Tourist Shopping Preferences and Expenditure Behaviors: The Case of

Taiwanese Outbound Market. Journal of Vacation Marketing 10(4):320-332. Lindberg, K., C. Tisdell, and D. Xue 2003 Ecotourism in China's Nature Reserves. In Tourism in China, A. Lew,

L. Yu, J. Ap, and G. Zhang, eds., pp. 103-122. The Haworth Hospitality Press. Little, J.D.C.

1970 Models and Managers: The Concept of a Decision Calculus. Management

Science 16(8):466-485.

Lodge, $\mathrm{D}$.

2008 Deaf Sentence. London: Penguin. 
MacCannell, D.

1973 Staged Authenticity: Arrangements of Social Space in Tourist Settings. American Journal of Sociology 79(3):589-603.

1976 The Tourist: A New Theory of the Leisure Class. New York, NY: Schoecken.

Magnini, V.

2003 A Look at Changing Acculturation Patterns in the United States and Implications for the Hospitality Industry. Journal of Human Resources in Hospitality and Tourism 2(2):57-74.

Mannell, R., and S.E. Iso-Ahola

1987 Psychological Nature of Leisure and Tourism Experience. Annals of Tourism Research 14(3):314-331.

March, R., and A. Woodside

2005 Tourism Behaviour: Travellers' Decisions and Actions. Wallingford: CABI.

Martin, G.N., N.R. Carlșon, and W. Buskist 2007 Psychology (3rd edition). Harlow: Pearson.

Martinetz, T., and K.J. Schulten 1994 Topology Representing Networks. Neural Networks 7(5):507-522.

Martinetz, T.M., S.G. Berkovich, and K.J. Schulten 1993 "Neural Gas" Network for Vector Quantization and Its Application to Time-

Series Prediction. IEEE Transactions on Neural Networks 4(4):558-569. Maslow, A.

1954 Motivation and Personality. New York, NY: Harper.

Mazanec, J.A.

1972 Über den Wissenschaftslogischen Standort der Werbelehre. Jahrbuch der

Absatz- und Verbrauchsforschung 12(1):63-72.

1978 Strukturmodelle des Konsumverhaltens. Vienna: Orac.

1979a Probabilistische Messverfahren in der Marketingforschung: Ein empirischer Anwendungsversuch zur Planung Absatzwirtschaftlicher Strategien des Imagetransfers. Marketing ZFP 2(3):174-186.

1979b Sortierprobleme des Marketingforschers in 'großen' Stichproben: Ein Praktikables Clusteranalytisches Verfahren mit Empirischem Demonstrationsbeispiel. Der Markt $68+69(4+1): 140-150$.

1979c Zielgruppenplanung im Fremdenverkehrsmarketing: Empirische Ergebnisse einer Segmentierungsanalyse der Österreichischen Urlaubsreisenden. Journal für Betriebswirtschaft 29(3):176-193.

1979d Voraussetzungen Rationaler Entscheidüngsvorbereitung im Fremdenverkehrsmarketing unter Rücksicht auf Neuere Analysemethoden. Der Markt 71(3):190-204.

1981a The Tourism/Leisure Ratio: Anticipating the Limits to Growth. Revue de Tourisme 38(4):2-12.

1981b Über den Einsatz der Verbundmessung zur indirekten Erfassung der Präferenzwirksamkeit einzelner Produkteigenschaften. Zeitschrift für Marktund Meinungsforschung 23+24:5261-5289. 
1982 Practicing the Causal Approach to Consumer Behavior Model Building: An Example from Tourism Research. Der Markt 84(4):127-138.

1983 Tourist Behavior Model Building: A Causal Approach. Revue de Tourisme 38(1):9-18.

1984 How to Detect Travel Market Segments: A Clustering Approach. Journal of Travel Research 23(1):17-21.

1986a A Decision Support System for Optimizing Advertising Policy of a National Tourist Office: Model Outline and Case Study. International Journal of Research in Marketing 3(2):63-77.

$1986 \mathrm{~b}$ Allocating an Advertising Budget to International Travel Markets. Annals of Tourism Research 13(4):609-634.

1990 An Expert System Approach to Travel Counseling. In The Tourism Connection: Linking Research and Marketing, 21st Annual Conference, pp. 81-87. Salt Lake City, UT: Travel \& Tourism Research Association. 1992 Classifying Tourists into Market Segments: A Neural Network Approach. Journal of Travel and Tourism Marketing 1(1):39-59.

1993 European Lifestyles and Tourism: 'Exporting' the EUROSTYLES to the USA. International Journal of Contemporary Hospitality Management 5(4):3-9.

1995 Positioning Analysis with Self-Organizing Maps: An Exploratory Study on Luxury Hotels. Cornell Hotel and Restaurant Administration Quarterly 36(6):80-96.

2000 Mastering Unobserved Heterogeneity in Tourist Behavior Research. Tourism Analysis 5(2-4):171-176.

2001 Neural Market Structure Analysis: Novel Topology-Sensitive Methodology.

European Journal of Marketing 35(7-8):894-914.

2002a Tourists' Acceptance of Euro Pricing: Conjoint Measurement with Random Coefficients. Tourism Management 23(3):245-253.

2002b Introducing Learning and Adaptivity into Web-Based Recommender Systems for Tourism and Leisure Services. Tourism Review 57(4):8-14.

2005 New Methodology for Analyzing Competitive Positions: A Demonstration

Study of Travelers' Attitudes Toward Their Modes of Transport. Tourism Analysis 9(4):231-240.

2006 Evaluating Perceptions-Based Marketing Strategies: An Agent-Based Model and Simulation Experiments. Journal of Modelling in Management 1(1):52-74.

2007a New Frontiers in Tourist Behavior Research: Steps Toward Causal Inference from Non-Experimental Data. Asia Pacific Journal of Tourism Research 12(3):223-235.

2007b Exploring Tourist Satisfaction with Nonlinear Structural Equation Modeling and Inferred Causation Analysis. Journal of Travel and Tourism Marketing 21(4):73-90.

2009 Tourism-Receiving Countries in Connotative Google Space (available online). Journal of Travel Research. 
Mazanec, J.A., and A. Ring

Tourism Destination Competitiveness: Second Thoughts on the World Economic

Forum Reports 2008 and 2009. Tourism Economics.

Mazanec, J.A., and H. Strasser

2000 A Nonparametric Approach to Perceptions-Based Market Segmentation:

Foundations. Vienna: Springer.

2007 Perceptions-Based Analysis of Tourism Products and Service Providers.

Journal of Travel Research 45(4):387-401.

Mazanec, J.A., and K. Wöber, eds.

2009 Analysing International City Tourism. (2nd edition). Vienna: Springer.

Mazanec, J.A., A. Ring, B. Stangl, and K. Teichmann

2010 Usage Patterns of Advanced Analytical Tools in Tourism Research

1988-2008: A Six Journal Survey. Journal of Information Technology and

Tourism. 12(1):17-46

Mazanec, J.A., G.I. Crouch, J.R. Brent-Ritchie, and A.G. Woodside, eds.

2001 Consumer Psychology of Tourism, Hospitality, and Leisure, Vol. 2.

Wallingford: CABI.

Mazanec, J.A., K. Wöber, and A.H. Zins

2007 Tourism Destination Competitiveness: From Definition to Explanation?

Journal of Travel Research 46(1):86-95.

McCabe, $\mathrm{S}$.

2002 The Tourist Experience and Everyday Life. In The Tourist as a Metaphor of

the Social World, G.M.S. Dann, ed., pp. 61-75. CABI.

McGuire, F.A., C.N. William, and J.T. O'Leary

2004 Constraints to Participation in the Arts by the Young Old, Old and Oldest

Old. Advances in Hospitality and Leisure 1:43-58.

McIntosh, R.W.

1992 Early Tourism Education in the United States. Journal of Tourism Studies 3(1):2-7.

Mehrabian, A., and J.A. Russell

1974 An Approach to Environmental Psychology. Cambridge, MA: MIT Press.

Melton, A.W.

1933 Studies of Installation at the Pennsylvania Museum of Art. Museum News 12:5-8.

1936 Distribution of Attention in Galleries in a Museum of Science and Industry.

Museum News 14:5-8.

1972 Visitor Behavior in Museums: Some Early Research in Environmental

Design. Human Factors 14:393-403.

Meridith, S., N. Wenger, H. Liu, N. Harada, and K. Khan

2000 Development of a Brief Scale to Measure Acculturation among Japanese

Americans. Journal of Community Psychology 28(2):103-113.

Mitchell, J.

2006 Food Acceptance and Acculturation. Journal of Foodservice 17(1):77-83. 
Money, B., and J. Crotts

2000 Buyer Behavior in the Japanese Travel Trade: Advancements in Theoretical

Frameworks. Journal of Travel and Tourism Marketing 9(1-2):1-19.

Montague, R.

2006 Why Buy This Book? How We Make Decisions. London: Penguin Books.

Montana, J. ed.

1994 Marketing in Europe: Case Studies. London: Sage.

Morris, D.

1968 The Naked Ape. London: Pan.

Morrison, A., and G.B. O'Mahony

2003 The Liberation of Hospitality Management Education. International Journal

of Contemporary Hospitality Management 15(1):38-44.

Moscardo, G.

1998 Interpretation and Sustainable Tourism: Functions, Examples and Principles. Journal of Tourism Studies 9(1):2-13.

1999 Making Visitors Mindful: Principles for Creating Quality Sustainable

Visitor Experiences through Effective Communication. Champaign, IL:

Sagamore Publishing.

Moscardo, G., A. Morrison, P. Pearce, C. Long, and J. O'Leary

1996 Understanding Vacation Destination Choice through Travel Motivation and

Activities. Journal of Vacation Marketing 2(2):109-122.

Moscardo, G., P. Pearce, A. Morrison, D. Green, and J.T. O'Leary

2000 Developing a Typology for Understanding Visiting Friends and Relatives

Markets. Journal of Travel Research 38(3):251-259.

Mowforth, M., and I. Munt

1998 Tourism and Sustainability: Development and New Tourism in the Third

World (2nd edition). London: Routledge.

Mykletun, R., J. Crotts, and A. Mykletun

2001 Positioning an Island Destination in the Peripheral Areas of the Baltics:

A Flexible Approach to Market Segmentation. Tourism Management 22(5): 493-500.

Nash, D.

1981 Tourism as an Anthropological Subject. Current Anthropology 22(5):461-481.

Nash, D. ed.

2007 The Study of Tourism Anthropological and Sociological Beginnings.

Amsterdam: Elsevier.

New Mexico Commission on' Professionalism

1999 <http://www.nnmcle.org/rules/prof.guidelines.asp > (Accessed October 8, 2006).

Nisbett, R.E.

2003 The Geography of Thought. London: Brearley.

Noe, F.P.

1999 Tourism Service Satisfaction. Champaign, IL: Sagamore. 
Noy, C.

2007 A Narrative Community. Detroit, MI: Wayne State University Press.

O'Leary, J.T.

1999 International Travel and Resource Management. In Outdoor Recreation

in American Life, K. Cordell, ed., pp. 294-298. Champaign, IL: Sagamore Publishing.

2005 Thoughts on Building Academic Staff Careers and a Successful Department.

Journal of Tourism Studies 16(2):14-20.

O'Leary, J.T., and M. Uysal

1986 A Canonical Analysis of International Tourism Demand. Annals of Tourism

Research 13(4):651-656.

O'Leary, J.T., and S.M. Meis

1999 International Tourism: Current Trends and Market Research with

Implications for Managing Public Attractions. In Ecosystem Management:

Adaptive Strategies for Natural Resource Organizations in the 21 st Century, J.

Aley, W.R. Burch, B. Conover, and D. Field, eds., pp. 17-24. Philadelphia, PA:

Taylor \& Francis.

O'Leary, J.T., F.A. McGuire, and F.D. Dottavio

1986a Outdoor Recreation and the Third Age: Results of the United States

Nationwide Recreation Survey. Leisure and Recreation 28(2):18-21.

O'Leary, J.T., F.D. Dottavio, and F.A. McGuire

1986b Constraints to Participation in Outdoor Recreation across the Life Span.

The Gerontologist 26(5):538-544.

Oh, H., M. Uysal, and P. Weaver

1995 Product Bundles and Market Segmentation Based on Travel Motivations:

A Canonical Correlation Approach. International Journal of Hospitality Management 14(2):123-137.

Oh, Y.J., C.K. Cheng, X.Y. Lehto, and J.T. O'Leary

2004 Predictors of Tourists' Shopping Behaviour: Examination of Socio-

Demographic Characteristics and Trip Typologies. Journal of Vacation

Marketing 10(4):308-319.

Page, S.J.

2005 Academic Ranking Exercises - Do They Achieve Anything Meaningful? - A

Personal View. Tourism Management 26(5):663-666.

Park, S., H. Park, J. Skinner, S. Ok, and A. Spindler

2003 Mother's Acculturation and Eating Behaviors of Korean American Families in

California. Journal of Nutritional Education Behavior 35(May-June):142-147.

Pearce, D.

2008 Channel Performance in Multichannel Tourism Distribution Systems.

Journal of Travel Research 46(3):256-267.

Pearce, P.L.

1977 Mental Souvenirs: A Study of Tourist and Their City Maps. Australian

Journal of Psychology 29:203-210. 
1982 The Social Psychology of Tourist Behaviour. Oxford: Pergamon.

1988 The Ulysses Factor: Evaluating Visitors in Tourist Settings. New York, NY: Springer-Verlag.

1990 The Backpacker Phenomenon: Preliminary Answers to Basic Questions. Townsville: James Cook University of North Queensland.

1991 Travel Stories: An Analysis of Self-Disclosure in Terms of Story Structure, Valence, and Audience Characteristics. Australian Psychologist 26(3): 172-174.

1993 Defining Tourism as a Specialism: A Justification and Implications. Teoros International 1(1):25-32.

2004 The Functions and Planning of Visitor Centres in Regional Tourism. Journal of Tourism Studies 15(1):8-17.

2005a Tourist Behaviour: Themes and Conceptual Schemes. Clevedon: Channel View.

2005b Professing Tourism: Tourism Academics as Educators, Researchers and Change Leaders. Journal of Tourism Studies 16(2):21-33.

2009a The Relationship between Positive Psychology and Tourist Behavior Studies. Tourism Analysis 14:37-48.

2009b Now That Is Funny Humour in Tourism Settings. Annals of Tourism Research 36(4):627-644.

Pearce, P.L., and G. Moscardo

2007 An Action Research Appraisal of Visitor Centre Interpretation and Change.

Journal of Interpretation Research 12(2):29-50.

Pearce, P.L., and M. Caltabiano

1983 Inferring Travel Motivations from Travelers' Experiences. Journal of Travel

Research 22(2):16-20.

Pearce, P.L., and M. Fenton

1994 Multidimensional Scaling and Tourism Research. In Travel, Tourism, and

Hospitality Research: A Handbook for Managers and Researchers, J.R.B.

Richie, and C.R. Goeldner, eds., pp. 523-532. New York, NY: Wiley.

Pearce, P.L., A.M. Morrison, and J.L. Rutledge

1998 Tourism: Bridges across Continents. Sydney: McGraw-Hill.

Pearce, P.L., G.M. Moscardo, and G.F. Ross

1996 Tourism Community Relationships. Oxford: Pergamon.

Pearce, P.L., S. Filep, and G. Ross

2011 Tourists, Tourism and the Good Life. New York, NY: Routledge. Pearl, J.

2001 Causality: Models, Reasoning, and Inference (2nd Printing). Cambridge:

Cambridge University Press.

Pearson, M., and S. Sullivan

1995 Looking After Heritage Places - The Basics of Heritage Planning for Managers, Landowners and Administrators. Melbourne: Melbourne University Press. 
Peeters, P.M. ed.

2007 Tourism and Climate Change Mitigation: Methods, Greenhouse Gas

Reductions and Policies. Breda: NHTV.

Peeters, P.M., T. van Egmond, and N. Visser

2004 European Tourism, Transport and Environment (Final Version). Breda: NHTV CSTT.

Pizam, A.

2003 What Should Be Our Field of Study? International Journal of Hospitality Management 22(4):339.

2006 Are We Talking and Listening to Each Other? International Journal of Hospitality Management 25(3):345-347.

2007 Educating the Next Generation of Hospitality Professionals. International Journal of Hospitality Management 26(1):1-3.

2008a Green Hotels: A Fad, Ploy or Fact of Life? International Journal of Hospitality Management 28(1): 1 .

$2008 \mathrm{~b}$ What Is the Hospitality Industry and How Does It Differ from the

Tourism and Travel Industries? International Journal of Hospitality Management 28(2):183-184.

2008c Advances in Hospitality Research: From Rodney Dangerfield to Aretha

Franklin. Keynote Address Presented at the Council on Hospitality Management Education, Glasgow, United Kingdom, May 12-15.

Pizam, A., and Y. Mansfield, eds.

2000 Consumer Behaviour in Travel and Tourism. New York, NY: The Haworth

Hospitality Press.

Plog, S.

2004 Leisure Travel: A Marketing Handbook. Upper Saddle River, NJ: Pearson. Popper, K.R.

1994 Alles Leben ist Problemlösen, Über Erkenntnis, Geschichte und Politik.

Munich: Piper.

Prentice, R.

2004 Tourist Motivation and Typologies. In A Companion to Tourism, A. Lew,

C. Hall, W. Michael, and M. Allan, eds., pp. 261-278. Oxford: Blackwell Publishing.

Reason, J.

1974 Man in Motion. London: Weidenfeld \& Nicolson.

Reisinger, Y., and J. Crotts

2009 Applying Hofstede's National Culture Measures in Tourism Research: Illumi-

nating Issues of Divergence and Convergence. Journal of Travel Research 48(4).

Reisinger, Y., and L. Turner

2003 Cross Cultural Behaviour in Tourism. Oxford: Butterworth Heinemann.

Reisinger, Y., F. Mavondo, and J. Crotts

2009 A Comparison of the Importance Attached to Tourism Destination

Attributes: Western and Asian Groups. Anatolia 20(1):236-253. 
Reynolds, T.J., and J. Gutman

1984 Advertising Is Image Management. Journal of Advertising Research 24(1):27-36.

Robinson, E.S.

1928 The Behaviour of the Museum Visitor. Cited in Environmental Psychology,

P. Bell, J. Fisher, and R. Loomis (1978). Philadelphia, PA: W.B. Saunders.

Rosenow, J., and G. Pulsipher

1978 Tourism: The Good, the Bad and the Ugly. Lincoln, NE: Media Productions.

Rowan, $J$.

1998 Maslow Amended. Journal of Humanistic Psychology 38(1):81-93.

Rubenstein, C.

1980 Vacations. Psychology Today (May):62-76.

Rushton, P., H.G. Murray, and S.V. Paunonen

1983 Personality, Research Creativity, and Teaching Effectiveness in University

Professors. Scientometrics 5(2):93-116.

Ryan, C.

1980 Introduction to Hotel and Catering Economics. Cheltenham: Stanley Thornes. 1991 Recreational Tourism: A Social Science Perspective. London: Routledge.

1995a Conversations in Majorca - The over 55s on Holiday. Tourism Management 16(3):207-217.

1995b Researching Tourist Satisfaction: Issues, Concepts, Problems. London:

Routledge.

1997 The Tourist Experience: A New Introduction. New York, NY: Cassell.

1999 From the Psychometrics of SERVQUAL to Sex - Measurements of Tourist

Satisfaction. In Consumer Behavior in Travel \& Tourism, P. Abraham, and

M. Yoel, eds., pp. 267-286. Binghamtom, NY: Haworth Press.

2002 Tourism and Cultural Proximity: Examples from New Zealand. Annals of

Tourism Research 29(4):952-971.

2005 Ethics in Tourism Research: Objectivities and Personal Perspectives. In

Tourism Research Methods: Integrating Theory with Practice, B.W. Ritchie,

P. Burns, and C. Palmer, eds., pp. 9-20. Wallingford: CABI.

Ryan, C. ed.

2007 Battlefield Tourism: History, Place and Interpretation. Oxford: Pergamon.

Ryan, C., and B. Trauer

2005 Adventure Tourism and Sport - An Introduction. In Taking Tourism to the

Limits, C. Ryan, S.J. Page, and M. Aicken, eds., pp. 143-148. Oxford: Pergamon.

Ryan, C., and H. Gu

2010 Constructionism and Culture in Research: Understandings of the Fourth

Buddhist Festival, Wutäishan, China. Tourism Management 31(2):167-178.

Ryan, C., and I. Ninov

2009 Place Perceptions - The Relationship between Specific Sites and Overall Impression of Place: The Example of Dubai Creek and 'Greater' Dubai. Paper presented at EuroChrie, Helsinki, Finland. 
Ryan, C., and X. Cui

2009 Perceptions of the Impacts of Tourism - A Case Study of Ongoing

Research in Ankang, China. In Proceedings of the International Conference on the Development Trends of Tourism and Hospitality Industry and Education, Jinwen University of Science and Technology, Taiwan, September 25-26, 2009.

Ryder, A., L. Alden, and D. Paulhus

2000 Is Acculturation Unidimensional or Bidimensional? A Head to Head

Comparison in the Prediction of Personality, Self Identity, and Adjustment.

Journal of Personality Social Psychology 79(1):49-65.

Saaty, T.L.

1977 A Scaling Method for Priorities in Hierarchical Structures. Journal of

Mathematical Psychology 15(3):234-281.

Sagan, C.

1996 The Demon-Haunted World: Science as a Candle in the Dark. New York, NY: Ballantine.

Salzberger, $\mathrm{T}$.

2009 Measurement in Marketing Research: An Alternative Framework.

Cheltenham: Edward Elgar.

Sasidharan, V., F. Willits, and G. Godbey

2005 Cultural Differences in Urban Recreation Patterns: An Examination of Park

Usage and Activity Participation across Six Population Subgroups. Managing

Leisure 10(1):19-38.

Schewe, C.D., and R.J. Calantone

1978 Psychographic Segmentation of Tourists. Journal of Travel Research 16(3):14-20.

Schiebler, S., J. Crotts, and R. Hollinger

1995 Florida Tourists Vulnerability to Crime. In Tourism, Crime and

International Security, P. Abe, and Y. Mansfield, eds., pp. 37-50. London:

Wiley.

Schmitt, B.H.

2003 Customer Experience Management. Hoboken, NJ: Wiley.

Schreyer, R., and J.W. Roggenbuck

1978 The Influence of Experience Expectations on Crowding Perceptions and

Social-Psychological Carrying Capacities. Leisure Sciences 1:373-394.

Seligman, M.E.P.

2002 Positive Psychology, Positive 'Prevention, and Positive Therapy. In Hand-

book of Positive Psychology, C.R. Snyder, and S.J. Lopez, eds., pp. 3-9.

New York, NY: Oxford University Press.

2008 Positive Health. Applied Psychology: An International Review 57:3-18.

Sharpe, G.

1976 Interpreting the Environment. New York, NY: Wiley. 
Shepherd, R.

In Press Historicity, Fieldwork, and the Allure of the Post-Modern: A Reply to Ryan and $\mathrm{Gu}$. Tourism Management.

Simmel, G.

1950 The Sociology of Georg Simmel (translated by H. Woolf). New York, NY:

Free Press of Glencoe.

Sirgy, M., and C. Su

2000 Destination Image, Self-Congruity, and Travel Behaviour: Toward an

Integrative Model. Journal of Travel Research 38:340-352.

Smart, J.C., K.A. Feldman, and C.A. Etherington

2000 Academic Disciplines: Holland's Theory and the Study of College Students and Faculty. Nashville, TN: Vanderbilt University Press. Smith, V.

1977 Hosts and Guests: The Anthropology of Tourism. Philadelphia, PA: University of Philadelphia Press.

Smithson, M., P. Amato, and P.L. Pearce

1983 Dimensions of Helping Behaviour. Oxford: Pergamon.

Sneed, J.D.

1971 The Logical Structure of Mathematical Physics. Dordrecht: Reidel.

Snepenger, D., J. King, E. Marshall, and M. Uysal

2006 Modeling Iso-Ahola's Motivation Theory in the Tourism Context. Journal

of Travel Research 45:140-149.

Spiegel, B.

1961 Die Struktur der Meinungsverteilung im Sozialen Feld: Das Psychologische

Marktmodell. Stuttgart: Huber.

Spirtes, P., C. Glymour, and R. Scheines

2000 Causation, Prediction, and Search (2nd edition). Cambridge: MIT Press.

Stankey, G.H., and J. Wood

1982 The Recreation Opportunity Spectrum: An Introduction. Australian Parks and Recreation (February):6-15.

Stebbins, R.A.

1982 Serious Leisure: A Conceptual Statement. Pacific Sociological Review 25:251-272.

Stegmüller, W.

1969 Probleme und Resultate der Wissenschaftstheorie und Analytischen

Philosophie, Band I, Wissenschaftliche Erklärung und Begründung. Berlin: Springer.

1974 Probleme und Resultate der Wissenschaftstheorie und Analytischen

Philosophie, Band II, Theorie und Erfahrung. Berlin: Springer. Stringer, $\mathbf{P}$.

1984 Studies in the Socio-Environmental Psychology of Tourism. Annals of Tourism Research 11:147-166. 
Stringer, P., and P.L. Pearce

1984 Toward a Symbiosis of Social Psychology and Tourism Studies. Annals of

Tourism Research 11:5-17.

Tilden, $\mathbf{F}$.

1977 Interpreting Our Heritage (3rd edition). Chapel Hilf, NC: University of North Carolina Press.

Tolman, E.C.

1948 Cognitive Maps in Rats and Men. Psychological Review 55:189-208. Tribe, $\mathrm{J}$.

1997 The Indiscipline of Tourism. Annals of Tourism Research 24(3): 638-657.

2009 Philosophical Issues in Tourism. In Philosophical Issues in Tourism. J. Tribe, ed., pp. 3-22. Bristol: Channel View.

Tse, P., and J. Crotts

2005 Antecedents of Novelty Seeking among International Visitors: Hong

Kong's Visitors' Propensity to Experiment with Culinary Traditions. Tourism Management 26:965-968.

Turner, L., and J. Ash

1975 The Golden Hordes: International Tourism and the Pleasure Periphery.

London: Constable.

Uriely, $\mathrm{N}$.

2005 The Tourist Experience: Conceptual Developments. Annals of Tourism

Research 32(1):199-216.

Van Egmond, T.

2007 Understanding Western Tourists in Developing Countries. Oxon: CABI.

Van Raaij, W.F.

1986 Consumer Research on Tourism: Mental and Behavioral Constructs. Annals of Tourism Research 13:1-10.

Van Rekom, J.

1994 Adding Psychological Value to Tourism Products. In The Economic

Psychology of Travel and Tourism, J. Crotts, and W.F. von Raaij, eds., pp. 21-36. Binghamton, NY: Haworth Press.

1997 Deriving an Operational Measure of Corporate Identity. European Journal of Marketing 31(5-6):410-422.

Wang, $N$.

2000 Tourism and Modernity: A Sociological Analysis. Oxford: Pergamon.

Waters, S.R.

1966 The American Tourist. Annals of the Academy of Political and Social

Science 368:109-118.

Weinberg, St.

1994 Dreams of a Final Theory: The Scientist's Search for the Ultimate Laws of Nature. New York, NY: Vintage. 
Wells, W.D. ed.

1974 Life Style and Psychographics. Chicago, IL: American Marketing Association.

Wiseman, $\mathrm{R}$.

2007 Quirkology. London: MacMillan.

Woodside, A., G.I. Crouch, J.A. Mazanec, M. Oppermann, and M.Y. Sakai, eds. 2000 Consumer Psychology of Tourism, Hospitality, and Leisure. Wallingford: CABI.

Yin, R.K.

2009 Case Study Research. Los Angeles, CA: Sage.

Young, G.

1973 Tourism - Blessing or Blight? Harmondsworth: Penguin.

Zimbardo, P., and J. Boyd

2008 The Paradox of Time. London: Rider.

Zube, E., J. Crystal, and J. Palmer

1978 National Parks Visitors Centres. In Environmental Design Evaluation, A. Friedmann, C. Zimring, and E. Zube, eds. New York, NY: Plenum. 